\title{
Garrett e Saramago: viagens pela terra e escrita portuguesas
}

\author{
Amélia Cherulli Alsina*
}

Resumo: Este artigo tem como objectivo estabelecer um diálogo entre os autores José Saramago e Almeida Garrett a partir do cotejo entre as obras Viagem a Portugal e Viagens na minha terra. A análise desses textos levará em consideração a releitura que ambos empreendem da temática da viagem, depreendendo-se desse aspecto algumas reflexões sobre a identidade nacional portuguesa, para além dos recursos estilísticos por eles utilizados. Ver-se-á que é exactamente nos elementos que comprovam a modernidade precoce de Garrett que Saramago se apoia, tendo o escritor romântico exercido influência fundamental não só na escrita dessa Viagem saramaguiana, mas também em toda a sua linguagem literária.
Abstract: This article aims to establish a dialogue between José Saramago and Almeida Garrett, who respectively wrote Journey to Portugal and Viagens na minha terra. The analysis of these texts will take into consideration the new approach that both undertake about the theme of travel. Some considerations about the Portuguese national identity also result from this aspect, beyond the stylistic resources employed by the authors. This article intends to show that Saramago was influenced by the early modernity of Garrett, as this Romantic played an important crucial role not only in Saramago's Journey, but also in his entire literary practice.

Keywords: José Saramago; Almeida Garrett; travel; national identity.

A tentativa de aproximação entre Almeida Garrett e José Saramago pode causar certo estranhamento, já que esses autores e suas obras se situam em momentos literários distintos e distantes no tempo. É facto, porém, que essa relação é explicitamente reconhecida pelo próprio Saramago nas várias vezes em que expressou a sua admiração por esse escritor romântico, afirmando ter sido em muito influenciado por ele. Isso acontece, por exemplo, na entrevista concedida a Manuel Gusmão para a revista Vértice, em que ele afirma "O Garrett para mim é uma referência fundamental" e admite haver "uma relação muito directa" entre "este [seu] trabalho de ficcionista e o Almeida Garrett" (GUSMÃO, 1989, p. 98). Mais recentemente, questionado por Carlos Reis a respeito de "[rever-se] muito neste seu antepassado", responde

\footnotetext{
* Amélia Cherulli Alsina é formada em Letras-Língua Portuguesa pela Universidade de Brasília (UnB) e mestre em Literatura Portuguesa, com ênfase em Literatura Portuguesa Moderna e Contemporânea, pela Universidade de Lisboa, Portugal, tendo defendido a tese intitulada Viagens da minha terra: um encontro entre Garrett e Saramago.
} 
com a dupla afirmação: "Sim, sim, sobretudo nas Viagens. Todos nós temos uma memória vivíssima desse seu livro" (1998, p. 127). A obra Viagem a Portugal é também uma homenagem evidente ao clássico garrettiano, primeiramente não só pela clara intertextualidade pretendida no título, mas também pela dedicatória: “em lembrança de Almeida Garrett, mestre de viajantes".

É devido a essa reivindicação do próprio Saramago que se pretende verificar, neste artigo, as semelhanças entre as escritas desses autores, debruçando-se sobre estes dois textos - Viagens na minha terra e Viagem a Portugal. Pretende-se cotejar as obras com o objectivo de compreender como se dá o diálogo entre os autores principalmente no que se refere ao tema da viagem e ao estilo literário por eles desenvolvido. Ver-se-á também que esses elementos de ordem temática e estilística contribuem para a descrição de diferentes, mas em algum sentido muito semelhantes, retratos da terra portuguesa ${ }^{1}$.

\section{Viagens pela terra portuguesa}

Comparando-se as obras Viagens na minha terra e Viagem a Portugal, logicamente a primeira similaridade que vem à tona é o uso da temática da viagem pela própria terra. Essas viagens em direcção ao interior da terra portuguesa representam, nas obras, uma recusa da direcção marítima historicamente legitimada, simbolizando a necessidade, após um longo período da História portuguesa - caracterizado pela ânsia de desbravar novos mares e pela tendência à evasão - de voltar à própria terra, de redescobrir a própria nação. Para Teresa Cristina Cerdeira da Silva, o sentido tomado por Saramago nessa Viagem constitui-se de uma "lição garrettiana" por ele aprendida, representando, em ambos os textos, a "falência da imagem secular do país como cais de partida" e um meio de "desmontar a máscara do falso conhecimento nacional e de promover o discurso de apreensão de uma possível identidade portuguesa." Ver-se-á, neste trabalho, que são bastante especiais os retratos que esses autores pintam da nação.

Um outro aspecto que aproxima as duas obras é a recusa que ambos empreendem do género literário conhecido como "literatura de viagens". Nesse sentido, essas viagens são escritas não com a intenção de registrar o passo-a-passo dos viajantes ou de descrever detalhadamente as paisagens, pessoas e objectos encontrados pelo caminho, mas de utilizar esse tópico como

\footnotetext{
${ }^{1}$ Para um estudo mais detalhando desses aspectos nessas obras, incluindo também A jangada de pedra, de José Saramago, ver a tese de mestrado por mim defendida, intitulada Viagens da minha terra: um encontro entre Garrett e Saramago.
} 
motivo, instrumento de retórica ou de estética que leva a interpretações simbólicas e metafóricas significativas. Das Viagens, é bastante conhecido o célebre fragmento em que o narrador deixa clara a sua intenção de, mesmo utilizando-se da sua própria experiência de viagem até Santarém, ultrapassar o simples relato de viagem, contrariando, assim, as expectativas do leitor que estivesse à espera de que ele descrevesse "marco a marco, as léguas da estrada", "algarismo por algarismo, as datas de sua fundação", e de que se resumisse a "história de cada pedra, de cada ruína" (1983, p.239-240) ${ }^{2}$. Segundo Carlos Reis (2003), a intenção de Garrett é a de "refutar o paradigma das Impressões de Viagem, largamente popularizadas pela escrita romântica e pelo seu consumo burguês", negando "a viagem como inventário e relatório", transcendendo-a (REIS, 2003, p. 136-137). É válido lembrar, inclusive, da sequiência do fragmento acima referido, o tom irónico e até mesmo depreciativo com que o narrador se refere a esses textos tradicionais, afirmando ter mais o que fazer a dedicar-se a esse tipo de escrita (cf. REIS, 2003, p. 240).

Já a Viagem a Portugal tem um formato mais próximo do relato de viagem, pois a sequência dos lugares por onde o viajante passa é registada em pormenor, sendo reconhecida a presença, na Introdução desse livro, de alguns elementos comuns a esse tipo de narrativa, como a descrição de "lugares selectos da paisagem e da arte" e da "face natural ou transformada da terra portuguesa" (2002, p. 13) ${ }^{3}$. Porém, nessa obra, também se evidencia a mesma intenção de ultrapassar o simples documentário, pois o autor também recusa o relato de viagem como guia, roteiro ou catálogo. No mesmo texto introdutório, ele prepara o leitor para o facto de que o seu livro não é "um guia às ordens, ou roteiro que leva pela mão, ou catálogo geral", muito menos tem a função de "agência de viagens ou balcão de turismo" (p. 13). A noção de turismo é recusada pelo viajante, que prefere os percursos alternativos aos trajectos-modelo apresentados nos prospectos oferecidos pelas agências de viagem, avisando o leitor que foi "aonde sempre se vai, mas foi também aonde se vai quase nunca”. Sugere, dessa forma, uma crítica ao mercado de viagens, que privilegia quase sempre os mesmos sítios, em detrimento de outros, em seu entender, tão importantes quanto aqueles. É por isso que Maria Luísa Leal afirma ser essa obra “um guia turístico ao contrário, ou um guia do não-turista” (LEAL, 1999, p. 193).

\footnotetext{
${ }^{2}$ A partir de agora, todas as citações das Viagens na minha terra terão como referência a edição organizada por Augusto da Costa Dias (Lisboa: Estampa, 1983).

${ }^{3}$ Todas as citações referentes à Viagem a Portugal pertencem à edição de 2002 da Editora Caminho (Lisboa).
} 
Não sendo apenas descrição em série dos lugares por onde se passou, a viagem é utilizada, nas obras, em sentidos mais complexos, como o de descoberta e o de aprendizagem. Ao viajar por Portugal, esses viajantes entram em contacto com as várias faces da nação portuguesa, seja nos aspectos naturais e humanos, seja no histórico-social, sendo esses elementos motivo de deslocamento (já que é essa a alma da viagem), mas também de paragem. Afinal, como afirmou o viajante saramaguiano, "Viajar deveria ser outro concerto, estar mais e andar menos" (p. 18). Sendo assim, esses elementos acabam por tornarem-se motivos de redescoberta da terra portuguesa e de redefinição do sentimento dos viajantes em relação à sua própria terra - razão pela qual também desencadeiam um processo de auto-aprendizagem.

Nesse sentido, do cotejo entre as Viagens na minha terra e a Viagem a Portugal, pode depreender-se um diálogo interessante entre os autores, que mostram interesses em comum, os quais definirão os motivos de movimento e de paragem nessas viagens. É o caso, por exemplo, das paisagens naturais portuguesas, que, apesar de muitas vezes decepcionarem ambos os viajantes pela não-preservação ambiental, são contempladas atentamente por eles, que as percebem não só física, mas também emocionalmente. O vale de Santarém, por exemplo, é descrito como um lugar onde devem viver "a paz, a saúde, o sossego do espírito e o repouso do coração", triunfando "ali um reinado de amor e benevolência", como "o Éden que o primeiro homem habitou com a sua inocência e com a virgindade do seu coração" (p. 132). Essa descrição prepara o leitor para a apresentação da personagem Joaninha, cujas características condizem perfeitamente com a da paisagem onde ela vive, mas se deve lembrar que essa admiração acabará por ser frustrada, devido ao destino da personagem Carlos (que opta por valorizar o social, não o natural) e ao fim trágico da novela. Saramago também fica encantado com as paisagens naturais da sua terra, sendo, na maioria das vezes, crítico em relação às paisagens artificiais. Isso fica evidente, por exemplo, na descrição do hotel do Buçaco - para ele capricho de um "milionário americano" (p. 149) -, em contraste com a da mata ao redor - exuberância que o deixa em "pasmo", totalmente entregue. A oposição entre o Palácio da Pena - irritante mistura de estilos artísticos - e o horizonte visto de lá - massa verde que causa vertigem - ou entre a pedra bruta pulsante - e a pedra polida - fria - utilizadas na construção das igrejas também enfatiza a opção pelo Portugal natural como um dos motivos de viagem.

Esses viajantes também vão em busca do património histórico e artístico português, incluindo as igrejas (vistas por ambos mais como representação estética do que religiosa). Nesse 
sentido, tanto o viajante garrettiano cujo destino principal é "a mais histórica e monumental" (p. 84) das vilas portuguesas, estando este "alvoroçado e impaciente" por se "achar face-a-face com aquela profusão de monumentos e ruínas" (p. 231), quanto o saramaguiano, que viaja em busca dos mesmos elementos, afinal "não lhe cabe tempo para mais indagações que as da arte e da história" (p. 171), acabam por empreender viagens que, a par de se darem no espaço, dão-se também no tempo. O narrador da Viagem a Portugal é mais explícito ao referir esse tipo de deslocamento, afirmando, por exemplo, ao entrar na igreja de São Cristóvão, em Rio Mau, que se sente "como se estivesse no interior duma máquina do tempo" (p. 68) ou, ao visitar os dólmenes da Queimada e sentir-se em total sintonia com o espaço natural, que se "retira do mundo", "Vai ali à Pré-História e volta já, cinco mil anos lá para trás” (p. 53).

Esse deslocar-se no tempo é um elemento importantíssimo nessas obras, pois, muitas vezes, ao invés do tão esperado encontro com o passado português, o que acaba por ocorrer é um desencontro. Bastante representativos dessa falência do ideal histórico são os momentos em que os viajantes narram o encontro com algumas importantes figuras históricas. Ao passear por Santarém, o narrador das Viagens vai à procura de algum "vestígio" de Nun’Álvares Pereira e imagina-o a passear pela Ribeira, “dando a 'correger' a bela espada velha de seu pai ao rústico profeta que tantos vaticínios de grandeza lhe fez, que o saudou condestável, conde de Ourém e salvador da sua pátria". O resultado é que "Nada [se pôde] descobrir que a imaginação se iludisse sequer", afinal "As emplastagens e replastagens sucessivas têm anacronizado tudo" (p. 285). Na Viagem a Portugal, em visita a Guimarães, a cujo castelo o viajante chega com a expectativa de encontrar o "berço da nacionalidade" portuguesa, ele se depara com uma paisagem de tal modo diferente, devido ao "exagerado restauro", que imagina a irónica cena de Afonso Henriques a chegar de alguma batalha e a perder-se no caminho de entrada do castelo, ao mesmo tempo que o empregado do jardim, após dar-lhe as direcções, comenta: "Vê-se cada um.". Nesse caso, afirma o narrador, ao invés de "o rio da história lhe [entrar] de repente no peito", encontra-se "um pequeno fio de água que constantemente se afunda e some nas areias do esquecimento" (p. 60). Nesses exemplos, é tamanha a similaridade entre as cenas que o período de tempo que separa os autores deixa de existir, e eles conseguem dialogar intensamente, concordando com o facto de que a nação acabará por ruir se não houver uma preocupação em preservar essa memória pátria.

Nas Viagens, ao procurar os monumentos nacionais (e encontrá-los destruídos) ou as sepulturas dos reis portugueses (e achá-las vazias), o narrador considera deparar-se com a 
imagem de uma nação semi-destruída e, de um ponto de vista extremo, inexistente. Para Victor Mendes, a "observação empírica dos monumentos" acaba por perturbar a "retórica da defesa do passado" (1999, p. 105), tornando-se, assim, mais um motivo da "crise da representação", que, para esse crítico, existe em vários níveis na obra. Na verdade, a crítica maior à nação portuguesa nessas Viagens voltar-se-ia para o presente, esta "modernidade deplorável", já que "revela uma inadequação para representar o passado", para gerir o "Portugal antigo". Para outro crítico, Pedro Serra, o "livro de pedra" que é Santarém - e, por sinédoque, Portugal - "é signo da amnésia, do esquecimento" (2003, p. 188), sublinhando a "disjunção entre a 'grandeza antiga' e a 'desgraça presente", (2003, p. 193).

Quanto ao Saramago da Viagem a Portugal, levando-se em conta seu próprio comentário de que essa sua obra "é o último livro de um Portugal que já não existe, que estava a deixar de existir naquele momento" (1998, p. 118) - o que se deve já à consciência da entrada do país em uma certa modernidade -, pode, então, considerar-se que a obra representa uma espécie de balanço histórico da nação, necessário à entrada em uma nova era. Nesse caso, entrevê-se um diálogo com o escritor romântico, já que ambos descrevem uma nação perto do fim, mas deve-se ressaltar que o ponto de vista do autor contemporâneo parece ser mais optimista, pois ele vê ainda a possibilidade de que o país consiga preservar um passado já quase esquecido. Ao afirmar, mais adiante na mesma entrevista, que o livro "mostra a última imagem de qualquer coisa" (1998, p. 118), ele também prevê um Portugal à beira da morte, mas não já no túmulo, significando a viagem por ele feita e o seu registo justamente a resistência ao Portugal-ninguém, ao Portugal fantasmático garrettiano. O último capítulo da Viagem a Portugal, em que o viajante afirma que a viagem, afinal, não acabara - porque os viajantes, mesmo quando não mais existem, "podem prolongar-se em memória, em lembrança, em narrativa” (p. 387) -, confirma a intenção de o autor, por meio da sua obra, contornar o pessimismo garrettiano quanto ao presente e de contribuir para a construção do futuro.

Esse desencontro (ou pelo menos esse encontro imperfeito) com o Portugal histórico faz com que eles também vão à procura de outro tipo de manifestações históricas e artísticas - as populares, aquelas que têm o resquício do linguajar comum e das mãos humanas portuguesas, nas palavras de Saramago o "murmúrio do profundo rio que é o povo" (p. p. 61) A comparação, por exemplo, entre ílhavos e campesinos nas Viagens e a descrição do festival de cantares alentejanos na Viagem mostram a valorização que se faz dos traços humanos portugueses, resgatando sua 
variedade e/ou particularidade física. Já as histórias populares de Santa Iria, do roubo da estátua de São Frei Gil e do homem de botas, assim como as do soldado José Jorge, do fantasma de José Júnior e do escravo preto são a revelação da voz popular portuguesa, responsável por guardar em memória alguns factos esquecidos ou não considerados pela História oficial. É interessante observar que a prática do ouvir, apreciada por ambos os viajantes, propicia um exercício narrativo particular, que é o de apropriação e reformulação, pelo narrador, da voz do outro, construindo, segundo as palavras de Genette, um “discurso narrativizado" (apud REIS, 2001, p. 36). Ou seja, outra personagem conta-lhe o caso ou é a voz da memória colectiva que se faz ouvir. A própria novela da "menina dos rouxinóis" e o caso de José Jorge, por exemplo, começam por ser contados pelas personagens encontradas pelo caminho (o companheiro de viagem ou o funcionário do cemitério), mas, depois, são concluídos pelo próprio narrador, que mescla o que acabara de ouvir com reflexões e factos que emanam da sua imaginação (recurso semelhante ao de Garrett).

Quanto a esse aspecto, é interessante observar como, nessas viagens, não só se pára para ouvir histórias, mas estas também são provocadas, tamanho é o gosto de ouvi-las. Nas Viagens, por exemplo, ao chegar ao café do Cartaxo, o viajante insiste para que o dono do estabelecimento conte "alguma coisa da terra". Apesar de resistir, o senhor acaba por contar a história do "Alfageme" (p. 118), com a qual o viajante e os seus companheiros de viagem se deliciam. Na Viagem a Portugal, o viajante se comporta da mesma maneira ao conhecer o senhor Guerra, na Guarda. Após o jantar, reconhecendo nesse chefe de mesa a possibilidade de ouvir uma história, o viajante vai estimulando-o, procurando "a pergunta que melhor sirva para abrir a arca que adivinha", até que ele alcança o seu propósito: "a arca abre-se por si própria e mostra o que tem dentro, um caso vulgar em terras condenadas como a de Cidadelhe" (p. 157). Ele consegue, portanto, ouvir mais uma história pela voz do homem comum.

Não há dúvidas de que esse apreço pelas histórias comuns, transmitidas de geração em geração, é mais um elemento de aproximação entre os autores estudados - ambos cumprem muito bem a função de legitimar a voz popular -, mas não se pode esquecer algumas importantes diferenças. Se Garrett, com seu olhar nacionalista, coloca lado a lado a História oficial e a popular, atribuindo a elas a mesma importância, Saramago tende a ser extremamente crítico com os factos históricos e com os heróis nacionais, sobrevalorizando a memória e a voz do povo. Enquanto o outro aceita o discurso oficial (e é por isso que ele tanto se decepciona com a não 
preservação de seus símbolos), este na maioria das vezes recusa essa História que "se atravanca de nomes" e reinventa para si um novo conceito, o da "história dos homens", dos "objectos e das palavras que os nomeiam, e dos nexos existentes entre eles e elas, mais os usos e os desusos, o como, o para quê, onde e quem produziu" (p. 290-291).

Não só as histórias populares são valorizadas, mas igualmente a literatura nacional e a universal, que também surgem como elemento de definição do percurso nessas obras. Não é à toa que o incipit de ambas está relacionado mais com questões de ordem literária que viática: assim como nas Viagens, cuja referência ao texto de Xavier de Maistre dá início ao percurso, na Viagem a Portugal alude-se ao Padre António Vieira, firmando-se, assim, já desde as primeiras linhas, um diálogo intertextual. Nas Viagens, por exemplo, para além das várias reflexões e citações do narrador sobre géneros e textos literários, fica bastante claro o papel desses na definição do itinerário. Por exemplo, o caminho para Azambuja - "aquela antiga selva, temida quase religiosamente como um bosque druídico!" (p. 104) - é repleto de expectativas quanto ao espaço mítico construído pela imaginação infantil e perfeito para que se desenrolassem as histórias lidas e ouvidas em criança (as de Pedro Malas-Artes e as de Schiller). Ao contrário, porém, o viajante é acometido de grande decepção, já que ele encontra, na verdade, "uns poucos pinheiros raros e enfezados" que lhe causam o "desapontamento mais chapado e solene" (p. 106) de toda a sua vida. Essa relação entre percurso e literatura também se evidencia no facto de que o viajante carrega livros consigo, o que se pode concluir do já citado comentário do narrador: "Se eu for algum dia a Roma, hei-de entrar na cidade eterna com o meu Tito Lívio e o meu Tácito nas algibeiras do meu paletó de viagem" (p. 224); ou na reflexão feita pelo narrador a respeito da leitura de um livro no local onde este foi escrito. Assim, a respeito da vantagem de ler-se Horácio em Roma, "pela Sacra via fora", ele afirma: "Deve ser maior prazer ainda, muito maior do que beijar o pé ao papa" (p. 225).

Na Viagem a Portugal, o diálogo com essa última citação fica muito claro no momento em que o viajante visita a casa de Camilo Castelo Branco, pelo que comenta:

\footnotetext{
Hão-de perdoar-se ao viajante estas fraquezas: vir de tão longe, ter mesmo à mão de ver coisas tão ilustres como um palácio velho, dois vales, cada qual sua beleza, uma serra lendária, e correr, em alvoroço, a duas pobres aldeias, só porque ali andou e viveu Camilo Castelo Branco. Uns vão a Meca, outros a Jerusalém, muitos a Fátima, o viajante vai à Samardã. Por esta estrada seguiu, a cavalo ou de traquitana, o doido do Camilo quando jovem (p. 44).
}

Percebe-se, nessa declaração, à semelhança de Garrett, não apenas o simples interesse literário, mas uma admiração tão grande por esse tipo de texto que se aproxima do sagrado, já que 
esse viajante muitas vezes prescinde de tudo o que é atracção turística e também religiosa, para ir ao encontro da memória literária, essa que parece ser, sim, a sua religião. Desse modo, o viajante vai a muitos sítios apenas porque lá nasceu, morou, passou ou sobre ele escreveu, algum dia, um autor ou uma personagem literária.

Apesar desses pontos em comum, é interessante observar que, enquanto no título das Viagens se utiliza a preposição em ("na"), indicativa de espacialização, que faz de Portugal o espaço de viagem, na Viagem a Portugal, a preposição "a", de movimento, situa o viajante em uma posição externa a Portugal e faz dessa terra espaço de destino. Dessa forma, Portugal, que, no primeiro título, é tido como um espaço familiar, do qual o viajante faz parte e com o qual se identifica, estabelecendo com ele uma relação de proximidade e de familiaridade (é a identificação, típica do Romantismo, do indivíduo e do escritor com sua terra), no segundo tornase um espaço ficcionalmente estranho e distante, para o qual o viajante se dirige, vindo de longe para reencontrá-lo, (re)descobri-lo.

Vê-se, portanto, que Garrett e Saramago compartilham não só interesses - como a História e as histórias portuguesas, a natureza e a literatura -, mas também algumas opiniões em relação a eles. Apesar de os autores observarem a terra portuguesa sob diferentes perspectivas, as quais poderiam ser caracterizadas como interna e externa, épica e anti-épica ou ainda nacionalista e anti-epopéia nacionalista (o que também tem a ver com os diferentes contextos sócio-políticos e períodos literários em que viveram), ambos empreendem, com essas viagens, a redescoberta da terra portuguesa, contribuindo para, de certa forma, reescrever a história nacional. Já que aquilo que representa a História oficial está perdido (ou quase a se perder), os autores escrevem uma nova história, baseada na face natural e humana portuguesa, na voz popular, na literatura e na linguagem, sendo esse último elemento o foco de estudo da próxima parte deste artigo.

\section{Viagens pela escrita}

Não há dúvidas de que as viagens aqui em estudo também têm como propósito dar ensejo a um outro tipo de deslocamento: o da palavra escrita pelo papel em branco. Não é à toa que, nas Viagens na minha terra, o viajante carrega consigo um conjunto de pertences que está sempre à mão: o papel e a pena, esta que lhe cai da mão quando se depara com a estalagem de Azambuja (p. 94) e, ambos, encontrados, ao final da viagem, também nos bolsos da algibeira - "Meti a mão 
na algibeira, e não achei senão notas... papeis!” (p.338). É claro que esses apetrechos de escrita foram necessários para tomar notas a respeito da história da "menina dos rouxinóis", tornando-se úteis para a concretização do projecto principal desse viajante, vinculado à escrita. Esse tipo de relação pode ter sido mesmo intencional, já que, em vários momentos, principalmente ao fazer a transição entre os capítulos, Garrett parece querer fundir as noções de escrita e de viagem. No final do XXVI, por exemplo, quando o narrador afirma "não, minha senhora, a história ainda não acabou, quase se pode dizer que ainda ela agora começa; mas houve mutação de cena. Vamos a Santarém, que lá se passa o segundo acto” (p. 229), o sintagma final do primeiro período e o inicial do segundo revelam esse tipo de correlação, pois, ao invés de ocorrer a mudança de cena, como anunciado (o que teria a ver com a escrita), introduz-se uma intenção de mudança espacial (relacionada com a viagem propriamente dita). Outro exemplo interessante é a transição entre o capítulo III, encerrado com a frase "Caminhámos na mesma ordem até chegar ao famoso pinhal de Azambuja." (p. 99), e o V, iniciado por “Este é o pinhal de Azambuja?” (p. 104). Entre eles, ao invés da descrição do percurso concreto, habitual nos relatos de viagem, há todo um capítulo (o IV) de divagações sobre filosofia, poesia e política, delineando-se, assim, um caminho de palavras até chegar-se ao destino pretendido. Além desses e de outros exemplos, é bastante significativo o desfecho da narrativa - "Assim terminou a nossa viagem a Santarém; e assim termina este livro" (p. 338) -, construção cujo paralelismo insinua o igual valor dado à viagem descrita na obra e à concretização do livro.

A Viagem a Portugal - não sendo só a representação de um percurso viático - está também a serviço desta intenção outra, que é a de exercitar a escrita. Isso fica evidente na já citada entrevista concedida a Carlos Reis, quando o entrevistado afirma aceitar a proposta de "fazer uma viagem e depois [contar]" (p. 1998, p. 117) o que viveu, e na própria Introdução da obra, ao confirmá-la como "uma história" (p. 13) - declarações que confirmam a ideia de que talvez o que mais importasse não era o processo, a viagem, mas o resultado, ou seja, o texto escrito. Essa aproximação também é referida no corpo do próprio texto, quando, por exemplo, o viajante vai de Cidadelhe para Pinhal em companhia do senhor Guerra e conclui que "ficou amigo do chefe de mesa, ouviu, falou, perguntou e respondeu, fizeram ambos uma excelente viagem" (p. 161), viagem feita de (ou preenchida com) palavras.

Esse aspecto da linguagem literária comum aos autores também está de acordo com certas fórmulas expressas nos livros aqui em estudo e que eles tomam para si ao escrever. Garrett, em 
determinado momento das Viagens, afirma: "Andando, escrevendo, sonho, e ando, sonho e falo, sonho e escrevo" (p. 103), acções que confirmam, mais uma vez, o entrelaçamento entre o percurso de viagem e o de escrita, para além do próprio falar, que salienta o resgate do coloquial na sua linguagem. Também é de destacar-se, desse fragmento, a função que adquire o sonhar, provavelmente relacionado com as aparentes digressões que são próprias do autor. Já Saramago, na Viagem a Portugal, declara que "é isso que o viajante tem andado a tentar: aprender a ver, aprender a ouvir, aprender a dizer" (p. 152). Nessa sentença, para além de o autor reforçar a questão do processo de aprendizagem em que se constitui a obra, destaca-se a sequência verouvir-dizer, a qual também explicita o carácter tipicamente oral da sua escrita

Sendo assim, a oralidade, característica tão marcante na escrita desses dois autores, manifesta-se não só no uso de vocábulos, expressões, frases e construções gramaticais próprios da linguagem oral e popular, mas na própria melodia frásica, já que ambos apresentam um estilo muito próximo do falar. Óscar Lopes já comentou, a respeito de Garrett, sobre seu escrever "como se falasse alto", fala esta que "no entanto não deixa de ser literária, isto é, conscientemente artística", ou sobre "aquele sabor inimitável de quem finge que não escreve, mas apenas fala" (1997, p. 725-726). Saramago não só aprecia essa característica da escrita de seu mestre, tomando-a para si, mas leva essa tendência oralizante ao ponto máximo, inventando seu sistema de pontuação, totalmente inovador, o qual homenageia, no corpo do texto literário, a arte do contar histórias. Baptista-Bastos define esse evento na obra de Saramago como "realidade coral" (1986, p. 76), enquanto Vasco Graça Moura denomina essa técnica de "oralidade escrita", ou seja, "uma oralidade aparente, mediatizada pela escrita e na dependência desta" ou ainda "maleabilizada pelos processos estilísticos e simulatórios que só a escrita permite" (1986, p. 8). $\mathrm{Na}$ verdade, essa afirmação também pode estender-se a Garrett, já que ambos os escritores exploram o recurso da oralidade em suas narrativas sem, contudo, perder a noção do código escrito. Nas obras, a linguagem coloquial não é usada apenas pontualmente ou como registo do falar das personagens, mas convive naturalmente com a escrita mais formal. Dessa forma, a fala popular torna-se perfeitamente aceita e legítima, sendo essa união um contributo para a valorização do homem que a profere e das histórias que ele tem para contar.

Às características estilísticas elencadas até aqui, deve somar-se o estilo de escrita totalmente híbrido apresentado por esses autores. A despeito da sequência lógica e cronológica, opta-se, nessas obras, por uma espécie de passeio por diferentes géneros literários, fazendo com 
que aquilo que parecia ser um simples relato de viagem se torne, no decorrer do percurso, um experienciar de diferentes tipos textuais, os quais são efectivamente praticados no decorrer da narrativa. Nas Viagens, por exemplo, o narrador exercita a escrita ao redigir a novela da "menina dos rouxinóis", ao descrever o vale de Santarém, ao comparar a versão popular da lenda de Santa Iria com a erudita, ao contar a história do "homem das botas", tudo permeado por considerações de ordem reflexiva que fazem dela um texto com tendência marcadamente digressiva. Quanto à escrita de Saramago, ele própria a reconhece como "desprogramada" (1986, p. 40), sendo confessadamente esse um dos elementos que mais lhe interessam na obra romanesca de Garrett [na sua crónica intitulada "Viagens na minha terra", o autor contemporâneo considera que "o melhor das Viagens não é a Joaninha dos Olhos Verdes", mas "é exactamente a viagem - a crónica” (SARAMAGO, 1991, p. 622-624)]. Na Viagem a Portugal, essa característica fica bastante evidente, já que é o percurso de viagem que define a trajectória textual, estando, dessa maneira, as descrições, narrações e reflexões a serviço do acaso proporcionado pelos imprevistos encontrados pelo caminho.

Vale a pena ressaltar que a tendência ensaística desses autores consolida o carácter argumentativo atribuído às suas obras. Temas como a literatura, a arte, a História e o quotidiano portugueses, assim como a humanidade, a religião e questões filosóficas em geral, para além, é claro, da própria viagem e da própria escrita, podem gerar a interrupção da trajectória programada e o avanço por esse tipo especial de caminho, que é a digressão reflexiva. Essa tendência confirma-se como um dos princípios essenciais da escrita de Garrett, já que as Viagens, afirmou Carlos Reis, constitui-se de uma "narrativa "de tese",, ou seja, "instrumento de acção sobre as mentalidades, costumes sociais e esquemas ideológicos do seu tempo" (REIS, 2001, p. 43-44). Nesse sentido, a história de Carlos e Joaninha tem a função, entre outras, de comprovar a frágil posição do homem frente às oscilações dos sistemas sociais, já que essa personagem masculina trai a causa liberal e torna-se barão. Além disso, toda a obra é uma tentativa de desenvolver argumentos, como o da crueldade de toda guerra, o da "marcha do progresso social" (p. 91) e o da inevitável oscilação entre o materialismo e o espiritualismo, representados por Quixote e Sancho.

Quanto a Saramago, ele próprio afirma, em entrevista a Juan Arias: "quizá no sea un novelista, o que quizá lo que hago son ensayos [...] precisamente, porque la sustancia, la materia del ensayista, es él mismo" (apud ARIAS, 1998, p. 36) A despeito de a Viagem a Portugal não se 
constituir verdadeiramente de um romance, essa afirmação também pode estender-se a essa obra, já que o ideal nela subentendido, afirmou o próprio autor, é o de registar um importante momento da nação portuguesa, o da morte de uma nação antiga e a sua entrada na modernidade (REIS, 1998, p. 118). Isso sem contar os vários trechos reflexivos inseridos no relato, como a tentativa de desconstrução da noção de fronteira (mais especificamente entre Portugal e Espanha). Há, então, nessas obras, a intenção de clarificar certos pontos de vista, partindo não só das personagens, das acções em que elas se envolvem e das condições espaço-temporais, mas também da presença de um desenvolvimento argumentativo que se repete no decorrer dos textos. Deve-se lembrar que essas digressões são aparentes porque não significam verdadeiros afastamentos do objecto do discurso, estando, pelo contrário, extremamente integradas no desenrolar dos factos.

Ainda a respeito dessas digressões, um outro motivo que leva os autores a interromper o fluxo narrativo é a inserção de reflexões a respeito da própria escrita. Esses comentários estão comumente relacionados com a desconstrução da própria noção de relato de viagem, com dúvidas quanto a como descrever uma paisagem ou narrar determinado facto, com a dificuldade de expressar com palavras o que se vê ou sente e com a própria revelação ou explicitação dos recursos literários usados. No caso de Saramago, sendo ele um escritor contemporâneo, a presença de registos metaficcionais em seus romances pode ser considerada comum, registo do seu tempo. Já quanto a Garrett, sendo recurso pouco comum na sua época, principalmente em Portugal, esse tipo de estratégia torna-se mais uma evidência da sua precoce modernidade. Alguns críticos analisaram esta questão nas Viagens, entre eles Carlos Ceia, que, comparando-a com a obra de Sterne, afirma:

\footnotetext{
As estratégias narrativas de Tristram Shandy e Viagens na Minha Terra - digressões reflexivas, interrupções, desconstruções do tempo da narrativa, contrato ficcional com o leitor - são exercícios de crítica literária incorporados no romance, ou, se quisermos, são ficções do próprio exercício crítico da literatura, uma vez que incluem a exposição de uma teoria ou de certas convenções e a respectiva demonstração da sua falibilidade, expondo as suas limitações ou simplesmente mostrando como é que essas convenções de escrita operam. Esta circunstância define o que hoje se entende por metaficção (2003, p. 171).
}

Nesse comentário e no restante do texto em que se insere a citação, Ceia traz à análise das Viagens o conceito moderno de metaficção, referindo-se, por exemplo, à dificuldade expressa pelo narrador de descrever a estalagem de Azambuja, já que a realidade com que se depara não pode ser descrita de acordo com os estilos praticados na época, o clássico ou o romântico; ou à dúvida sobre como inserir a história de Joaninha na "grave Odisseia das [suas] viagens" (p. 138). 
Quando ele se propõe a escrever a novela de Carlos e Joaninha, começa por indagar-se: "como hei-de fazê-lo, eu que já não tenho que amar neste mundo senão uma saudade e uma esperança um filho no berço e uma mulher na cova?...” (p. 138); mas, após um diálogo com as leitoras e de algumas digressões que, por serem de carácter pessoal e confessional, não se estendem muito, afirma: "estou suficientemente habilitado para cronista da minha história" (p. 139). Essa revelação do fazer literário enfatiza a própria escrita, questiona os princípios estético-literários em voga no momento e dramatiza (não apenas ficcionaliza) o texto literário, que se torna personagem em palco actuando.

Nas obras de Saramago, os processos de escrita também são colocados em evidência. Na Viagem a Portugal, por exemplo, a própria ocorrência excessiva do sintagma "o viajante", a qual remete constante e repetidamente para a própria viagem e para seu relato, e as prolepses, que evidenciam a existência de um instância ficcional que controla totalmente a narrativa (o narrador), são já evidência desse exercício literário. Isso também ocorre nos comentários sobre a insuficiência do texto escrito na expressão da realidade, como no momento em que o viajante quer descrever convenientemente as paisagens e não consegue êxito, reflectindo: "Lástima tem o viajante de que uma linha de palavras não seja uma corrente de imagens, de luzes, de sons" (p. 56) ou "há mais paisagem à espera. E para esta não vão chegar palavras, nem pinturas, nem música" (p. 77). Esses exemplos ressaltam a dissociação entre a viagem e o relato: apesar de, nesse tipo de texto, pretender-se passar a impressão (ou a ilusão) de que ambos se realizam simultaneamente, esse é um exercício impossível, sendo a expressão das dificuldades do registo escrito já uma maneira de confessar a dissociação entre a prática e o documento.

As citações acima suscitam uma outra questão: o desejo de que o texto escrito aproveite alguns recursos dramáticos (imagem, luz, som) para que expresse mais claramente o que se pretende. Essa é uma reclamação em comum aos dois autores, já que, talvez devido a ambos terem feito as suas incursões pela escrita teatral, eles acabam por expressar, directa ou indirectamente, em suas obras, a falta que fazem algumas características do drama na escrita romanesca. Quanto às Viagens, Mário Vieira de Carvalho, no artigo intitulado "A cultura da escuta na novelística de Garrett", comenta a capacidade de o romancista compor "musicalmente" as cenas, com recursos como a descrição dos cenários, a expressividade dos sentimentos e, sobretudo, a sonoridade dos eventos, os quais intensificam "o efeito dramático de determinados eventos", definindo "afinidades com o universo da ópera romântica" (CARVALHO, 1999, p. 
131-139). Se o autor romântico chega a concretizar essa dramaticidade em seu texto, Saramago, pelo menos nessa Viagem, como se viu, limita-se a apelar a ela, mas abrindo já espaço para que, nas obras seguintes, ele reclame expressamente o facto de não ser o romance drama.

Essa multiplicidade de registos e géneros também abre caminho para uma discussão a respeito das instâncias narrativa e autoral nas obras. Para Victor J. Mendes, esse é mais um dos aspectos que contribuem para a "crise da representação nas Viagens", já que a figura do narrador nessa obra é mais complexa do que parece. Redigindo o texto ora na primeira, ora na terceira pessoa, denominando a voz narrativa ora "autor", ora "narrador" e, além disso, confundindo a voz autoral com a da personagem Carlos, Garrett empreende, na verdade, um projecto novo, que é o de construir um autor, segundo aquele crítico, "na acepção gramatical e ficcional", não "uma pessoa no importante sentido civil do termo" (1999, p. 24).

Na Viagem a Portugal, ocorre algo semelhante, já que, embora se saiba que o próprio José Saramago efectuou realmente uma viagem pelo país, a qual deu origem ao livro, há um esforço significativo do autor, no corpo do texto literário, para disfarçar esse facto biográfico em prol de tornar a narrativa um registo de viagem ficcional. A já referida invenção de uma voz narrativa extradiegética pode representar mesmo uma maneira de exercitar o romance de ficção, tendo em vista que essa obra se situa em uma posição de transição na produção literária de Saramago (cf. SEIXO, 1999, p. 21). Sua publicação, o próprio autor reconhece, representa um divisor de águas em sua carreira literária, sendo talvez esse exercício de criação de um narrador o aspecto mais importante para a sua obra posterior, decididamente romanesca.

A hibridez formal e temática, aliada à maneira complexa de lidar com esses elementos narrativos, constitui-se de um desafio ao leitor dessas obras. A figura do receptor, se é constantemente evocada por Garrett, que o denomina "benévolo leitor" ou "amável leitora", é indirectamente desafiada por Saramago, chamando-a a participar activamente com vistas a não se perder no vaivém narrativo e a decodificar as inovadoras estratégias literárias. Vale lembrar que o tratamento dado ao leitor nas Viagens é considerado por Victor Mendes mais um motivo da "crise da representação" nessa obra, já que a instâcia interpelada, ao invés de ser verdadeiramente chamada a participar, está, na verdade, sendo posta em causa, afinal o autor a evoca não para reconhecer verdadeiramente a sua importância, mas para, ironicamente, reforçar os seus próprios pontos de vista e confirmar a eficácia de seus estratagemas (MENDES, 1999, p. 259). Quanto a esse aspecto na obra de Saramago, Giuseppe Tavani afirma ser uma espécie de "jogo 
combinatório" o qual faz o leitor "ser levado a julgamento por uma provocação sistemática por parte do autor, que actua negando o que num primeiro momento expressara como verdade, e empurrando o leitor a percorrer com ele um dos itinerários possíveis que a história oferece" (TAVANI apud BAPTISTA-BASTOS, 1996, p. 89). Vê-se, assim, que também nesse aspecto Saramago dialoga com Garrett, mostrando ter aprendido, mais uma vez, muito bem a lição.

Ao estudar a escrita romanesca desses autores, também não se pode esquecer de referir as inúmeras citações que ambos inserem em seus discursos, tornando-se estes, nas palavras de Julia Kristeva (1978, p. 98), verdadeiros “mosaico[s] de citações”. Para além das referências à tradição da viagem na literatura, ao género literatura de viagens e à própria relação de intertextualidade existente entre esses autores, há, em suas obras, várias outras citações de textos da tradição literária e popular, que as tornam verdadeiras colchas de retalhos, cujas referências são, por vezes, facilmente reconhecíveis, outras nem tanto (já que variam da citação propriamente dita à alusão ou até mesmo à paródia).

A estratégia da citação propriamente dita foi mais usada, sem dúvida, por Garrett, que, nas Viagens, cita, por exemplo, a Bíblia, Santo Agostinho, Horácio, Camões e Goethe, autores que simbolizam a oscilação tão discutida nesta obra entre o clássico e o romântico. Esse autor também recorreu às célebres personagens de Cervantes; comentando, em vários momentos da obra, a tensão dialéctica entre o modo de ser Dom Quixote e o modo de ser Sancho Pança, o autor não só valoriza esse clássico da literatura universal, como, sobretudo, explica a ordem dos acontecimentos narrados nas Viagens, definindo o objectivo principal da obra: discutir a oscilação entre o homem natural e o social, a ciclicidade de ideais, da qual Carlos é representante exemplar. Vê-se, portanto, que também as citações presentes nessa obra estão a serviço dos argumentos que se quer provar.

Na Viagem a Portugal, Saramago reporta a uma série de autores da literatura portuguesa, de quem a personagem-viajante parece ir à procura para com eles dialogar. É extremamente revelador notar que, ao aludir a esses literatos, o autor faz uma selecção bastante rigorosa, não se referindo, por exemplo, a autores contemporâneos. Dos romancistas, aparecem Alexandre Herculano, Camilo Castelo Branco e Júlio Dinis, além de Garrett, obviamente, revelando-se uma ênfase no século XIX, em principal no Romantismo (período de consolidação do romance em Portugal); dos poetas, surgem D. Dinis, Luís de Camões, Augusto Gil, Mariana Alcoforado, Bocage, Fialho de Almeida, António Nobre, Teixeira de Pascoaes e José Régio, sequência que, 
curiosamente, recupera toda a tradição poética portuguesa desde as cantigas medievais até ao Modernismo. No que diz respeito aos cronistas, são referidos Fernão Lopes e Fernão Mendes Pinto, comprovando a maior confiança atribuída pelo viajante às crónicas, que estão na origem do registo histórico, em detrimento da História oficial. Depreende-se, assim, dessa selecção espécie de história literária portuguesa escolhida -, um apelo à conservação da memória daqueles que representam a tradição literária portuguesa, e também a intenção, presente em toda a obra, de recuperar as origens culturais e históricas de Portugal. Defende-se, na verdade, a história encontrada nas crónicas e narrativas de ficção dos seus antecessores, para ele mais autênticas e necessitadas de preservação, o que talvez justifique o vazio referente a escritores posteriores às primeiras décadas do século XX.

Nessa mesma obra, vale a pena focalizar o índice, no qual se encontram reunidos títulos e subtítulos que, lidos com atenção e muitas vezes pensados em voz alta, como o reivindica o autor para a leitura de sua obra, emitem uma sonoridade que remete para expressões da tradição oral. É o caso, por exemplo, dos títulos "De Nordeste a Noroeste, duro e dourado", "Brandas beiras de pedra, paciência" e "A grande e ardente terra do Alentejo", cujas aliterações lembram mesmo poesia; ou "Coimbra sobe, Coimbra desce", "Alta está, alta mora" e "Uma ilha, duas ilhas", dísticos cuja melodia é típica das cantigas populares; "Chaminés e laranjais", "Uma pedra velha, o homem", "O pulo e o salto", os quais remetem para títulos de fábulas; ou ainda "De Algarve e sol, pão seco e pão mole", "Males da cabeça e milagres vários" e "Quanto mais perto, mais longe", cujo paralelismo é o mesmo dos ditados. Além desses sons que, ao leitor atento ou acostumado à linguagem popular dos contos e narrativas orais, fazem lembrar o falar regional, há também os títulos que reportam a histórias outrora ouvidas, sejam elas portuguesas ou universais. São eles: "O sermão aos peixes", "Tentações do demónio", "O palácio da Bela Adormecida", "São Jorge saiu a cavalo", "O alimento do corpo", "Um castelo para Hamlet”, “ Hic est chorus", "Artes da água e do fogo", "Frades, guerreiros e pescadores", "O paraíso encontrado" ou "A noite em que tudo começou", que fazem lembrar (por causa da semelhança sintagmática ou de alguma palavra-chave) expressões ditas em outros momentos, repetidamente, seja na Bíblia, seja em textos da literatura universal. Ressalte-se a presença de frases como "Em Romeu, há o museu" (p. 28), "Tornou o viajante a Amarante" (p. 54) e "Do outro lado é Sanlucar e outro falar" (p. 369), e de outras como “A Estremoz irás, seus bonecos verás, tua alma salvarás” (p. 334) e "Cada um com cada qual, e tudo com Portugal" (p. 336), as quais remetem para a 
sonoridade da frase tipicamente popular e que fazem perceber uma intertextualidade subtil a perpassar toda a obra e que vem corroborar o que tem sido discutido até aqui sobre os ideais de revalorização do homem e do povo nela defendidos. Os autores, ao fazer de seus textos exercícios de intertextualidade, trazem ao presente do leitor um património linguístico e literário colectivo e universal que, aliado a outros aspectos anteriormente citados, contribui para que se (re)defina e preserve a nacionalidade portuguesa para eles mais autêntica.

Vê-se, portanto, a partir do cotejo entre essas duas obras, que, se entre Garrett e Saramago há obviamente uma distância temporal muito grande, eles acabam por aproximar-se nesta arte que é a da escrita. Esse contacto, procurado e conquistado por Saramago, revela o seu apreço pelo que há de mais autêntico, inovador e peculiar na obra desse seu sucessor, justamente os aspectos que definem a sua modernidade. Nesse encontro, o diálogo entre eles passa pela desconstrução da viagem como género literário, mas também pela revalorização dessa temática, por essa escrita que se quer fala e até mesmo música ou drama, por essa bagagem literária e cultural que se quer compartilhar e renovar a todo o tempo, por esse deambular por paisagens e histórias que definem a identidade pátria portuguesa. Assim, já que ambos se deparam com um Portugal em fase de transição e prestes a ser enterrado devido à desmemória, os autores parecem sentir-se responsáveis por preservar a memória nacional e, assim, assegurar a entrada em um novo período. A escrita e a própria publicação dessas obras tornam-se, nesse caso, fundamentais.

Deve-se ainda ressaltar que, se por um lado, Saramago não se limita a seguir o modelo, criando, a partir dele, um estilo muito próprio e original, por outro, ao trazer Garrett à luz novamente, relendo-o e dando-o a ler por meio da sua Viagem, ele contribui para a actualização desse ilustre representante do Romantismo em Portugal e evidencia, mais uma vez, a sua contemporaneidade. Nesse sentido, pode-se dizer que, assim como Garrett, Saramago tem um papel importante nessa missão de resgatar a lembrança do passado - tanto literário quanto histórico -, renová-la e abrir caminho para um porvir promissor, consciente da tradição literária a que pertence.

\section{Referências}

ALSINA, Amélia Cherulli. Viagens da minha terra: um encontro entre Garrett e Saramago. 174 fs. Dissertação (Mestrado em Estudos Românicos) - Universidade de Lisboa, Lisboa, 2006. 
ARIAS, Juan. El amor possible. Barcelona: Planet, 1998.

BAPTISTA-BASTOS. José Saramago - aproximação a um retrato. Lisboa: Dom Quixote/ Sociedade de Autores, 1986.

CARVALHO, Mário Vieira. A cultura da escuta na novelística de Garrett. Leituras: Revista da Biblioteca Nacional, Lisboa, série 3, n. 4, p. 125-146, abr-out. 1999.

CEIA, Carlos. Tristam Shandy e Viagens na minha terra: paradigmas da metaficção. In: MONTEIRO, Ofélia Paiva; SANTANA, Maria Helena (Org.). Almeida Garrett - um romântico, um moderno, v. 1. Lisboa: Imprensa Nacional-Casa da Moeda, 2003. p.159-176.

DIAS, Augusto da Costa. Garrett e os caminhos da doutrinação romântica. In: GARRETT, Almeida. Lendas e narrativas (Prefácio). Lisboa: Estampa, 1979. p. 19-27.

GARRETT, Almeida. Viagens na minha terra. Lisboa: Estampa, 1983.

GUSMÃO, Manuel. Entrevista com José Saramago. Vértice, Lisboa, n. 87, II série, p. 85-99, nov-dez. 1989.

KRISTEVA, Julia. Introdução à semanálise. São Paulo: Perspectiva, 1978.

LEAL, Maria Luísa. "Viagem a Portugal": os passos do viajante. José Saramago - o ano de 1998, Colóquio-Letras, Lisboa, n. 151-152, p. 191-203, jan/jun.1999.

LOPES, Óscar; SARAIVA, José. História da literatura portuguesa. Porto: Porto Editora, 1997.

MENDES, Victor J. A morte do leitor nas Viagens de Garrett. Colóquio-Letras, Lisboa, n. 153154, jul/dez.1999.

MENDES, Victor. Almeida Garrett - crise da representação nas Viagens na minha terra. Lisboa: Cosmos, 1999.

MOURA, Vasco Graça. O ano do prémio de Saramago. Jornal de Letras, Artes e Ideias, Lisboa, p. 8, 28 de Julho de 1986.

REIS, Carlos. As Viagens como hipertexto: hipóteses de trabalho. In: MONTEIRO, Ofélia Paiva \& SANTANA, Maria Helena (Org.). Almeida Garrett - um romântico, um moderno, vol. I. Lisboa: Imprensa Nacional-Casa da Moeda, 2003. p. 133-144.

Diálogos com José Saramago. Lisboa: Caminho, 1998.

Introdução à leitura das Viagens na minha terra. Coimbra: Almedina, 2001.

SARAMAGO, José. Viagem a Portugal. Lisboa: Caminho, 2002.

Obras de José Saramago (v. 1). Porto: Lello \& Irmão, 1991. 
SEIXO, Maria Alzira. Lugares da ficção em José Saramago. Lisboa: Imprensa-Nacional- Casa da Moeda, 1999.

SERRA, Pedro. Linguagem, memória e história nas Viagens na minha terra. In: MONTEIRO, Ofélia Paiva; SANTANA, Maria Helena (Org.). Almeida Garrett - um romântico, um moderno, vol. I. Lisboa: Imprensa Nacional-Casa da Moeda, 2003. p. 187-213.

SILVA, Teresa Cristina Cerdeira da. De viagens e viajantes. In: MONTEIRO, Ofélia Paiva; SANTANA, Maria Helena (Org.). Almeida Garrett - um romântico, um moderno, vol. 1. Lisboa: Imprensa Nacional-Casa da Moeda, 2003. p. 243-251. 